\title{
Sykepleiere på akuttmottak ønsker mer kunnskap om brannskader
}

De fleste sykepleiere som jobber på akuttmottak, synes at de kan for lite om hardt brannskadde pasienter. Hele 95,9 prosent ønsker mer opplæring.

Fredrik Berg

Akuttsykepleier

Akuttmottaket, Sykehuset i Vestfold

Marita Våge-Kimerud

Akuttsykepleier

Akuttmottaket, Sykehuset Telemark

Ann-Chatrin Linqvist Leonardsen

Førsteamanuensis og forsker

Høgskolen i Østfold og Sykehuset Østfold Kalnes

Akuttsykepleie

Kvalitet

Brannskade

Kvalitativ studie

Sykepleien 2019107 (79337) (e-79337)

DOI: 10.4220/Sykepleiens.2019.79337

\section{Hovedbudskap}

På akuttmottakene er det høyt tempo og uforutsigbarhet. Helsepersonell må ha høy kompetanse når de tar imot brannskadde pasienter. Studien viser at sykepleiere med videreutdanning har høyere egenopplevd kompetanse ved mottak av brannskadde pasienter enn sykepleiere uten videreutdanning. Majoriteten av sykepleierne $\varnothing$ nsker mer opplæring i og simulering av slike situasjoner. 
I Norge får om lag 15000 personer medisinsk behandling for brannskader årlig (1). Den medisinske behandlingen gjøres ikke nødvendigvis på sykehus, men hos fastlege, på legevakt eller skadepoliklinikk på sykehusene (2).

Mange av pasientene som blir eksponert for brannskader, forårsaker den selv, oftest ved uhell. Det er barn i o-9 års alder som er mest utsatt. I 2012 ble 620 personer innlagt på sykehus med brannskade. 375 pasienter hadde mer enn ett sykehusopphold, og 124 pasienter hadde opphold ved mer enn ett sykehus (3).

\section{三 «Det er barn i o-9 års alder som er mest utsatt.»}

Ofte forekommer det at brannskadde pasienter blir transportert til nærmeste lokalsykehus for å vurdere omfanget av skadene og/eller for å stabilisere pasienten før videre transport til brannskadeavsnittet på Haukeland universitetssjukehus.

Hos ti prosent av pasientene som kommer inn med brannskader, er det påvist ytterligere behov for behandling og innleggelse i en spesialavdeling (4). I slike tilfeller tas pasienten imot av et traumeteam, som består av leger, radiografer, bioingeniører og sykepleiere med og uten videreutdanning.

\section{Hensikten med studien}

Erfaringer tilsier at mange sykepleiere er usikre ved mottak av alvorlig brannskadde pasienter. Arsakene til dette kan være mangel på mengdetrening og erfaring i mottak av denne pasientgruppen. Hensikten med vår studie var å kartlegge følgende:

1. Hvilken erfaring har sykepleiere med mottak av hardt brannskadde pasienter, og hvordan vurderer de sin egen kompetanse i mottak av denne pasientgruppen?

2. I hvilken grad påvirker spesialutdanning sykepleiernes egenopplevde kompetanse?

3. I hvilken grad påvirker kurs i traumesykepleie (KITS) og opplæring opplevelsen av kompetanse?

Studien ble gjennomført ved to akuttmottak ved to ulike sykehus i Helse Sør- Øst. 


\section{Laget eget spørreskjema}

Et systematisk litteraturs $\varnothing \mathrm{k}$ med søkeordene nurse, competence, burns, emergency, brannskade ga få resultater. Søk etter validerte spørreskjema ga ingen resultater. Det ble derfor utarbeidet eget spørreskjema med utgangspunkt i teori, samt med utgangspunkt i teori om sykepleiekompetanse (5) og om mottak og behandling av brannskadde pasienter (2).

Spørreskjemaet ble utformet med 17 spørsmål fordelt på fire kategorier. De fire kategoriene var følgende:

1. Bakgrunn: sykepleier/spesialsykepleier med mer enn 90 studiepoengs videreutdanning, erfaring fra akuttmottak, deltakelse på kurs i traumesykepleie eller tilsvarende (tre spørsmål).

2. Erfaring: Har du tatt imot en hardt brannskadd pasient, og eventuelt hvor lenge er det siden? Har du mottatt opplæring/trening/simulering i mottak av en hardt brannskadd pasient, og ønsker du eventuelt mer av dette? (seks spørsmål).

3. Egenvurdering av kompetanse i mottak av hardt brannskadd pasient $(n=3)$. Svaralternativ fordelt på en 5poengs Likert-skala.

4. Teoretisk kunnskap (fem spørsmål): kunnskapsspørsmål med tre til fem svaralternativer formulert etter litteratur på tema fra brannskademanualen til Haukeland universitetssjukehus (2).

Det ble utført en pilotunders $\varnothing$ kelse (blant ti sykepleiere) som inkluderte et kort spørreskjema med fem spørsmål hvor det var ønskelig at respondentene utfylte svar på følgende:

- Var spørreunders økelsen grei å besvare?

- Var spørsmålene relevante?

- Var svaralternativene logiske?

- Var ordlyden godt formulert?

- Har du noen kommentarer, eller noe du synes var vanskelig å svare på?

Pilotunders $\varnothing$ kelsen medførte få endringer av spørreskjemaet. 


\section{Datasamling}

Inklusjonskriteriene for å delta var sykepleiere og spesialsykepleiere ansatt ved de to akuttmottakene, som jobbet i 50 prosent stilling eller mer direkte pasientrettet, ansatt i akuttmottakene (141 aktuelle sykepleiere).

Informasjon om studien ble sendt ut til alle ansatte sykepleiere ved de respektive avdelingene per e-post. Unders $\varnothing$ kelsen ble gjennomf $\varnothing$ rt i tidsrommet 11. februar-15. mars 2019.

\section{Analyse}

Data ble analysert ved hjelp av Statistical Package for the Social Sciences, SPSS, versjon 25.

Det ble benyttet deskriptiv statistikk og frekvensanalyser for å beskrive utvalget og fordeling av svarene. Siden data var normalfordelt, ble det benyttet t-tester, krysstabeller samt lineær regresjon for å sammenlikne sykepleiere og spesialsykepleiere samt effekten av deltakelse på kurs og/eller erfaring med mottak av brannskadde. Signifikansnivå ble satt til $\mathrm{p}<0,05$.

\section{Etiske betraktninger}

Godkjenning ble innhentet fra respektive ledere, lokalt personvernombud samt Norsk Senter for Forskningsdata (NSD) (ref. nr. 737097). Studien baserer seg på frivillig, informert samtykke.

\section{Resultater}

Av 141 inviterte sykepleiere var det 99 respondenter (70,2 prosent). Fordelingen av respondenter mellom de to avdelingene var henholdsvis 44 respondenter ved sykehus 1 og 55 respondenter ved sykehus 2 .

Tabell 1 viser en oversikt over respondentenes bakgrunn, erfaring og kursdeltakelse.

Tabell 1. Deskriptiv oversikt over respondentenes bakgrunn, erfaring og kursdeltakelse

\begin{tabular}{lccc} 
Bakgrunn & $\begin{array}{l}\text { Erfaring fra akuttmottak } \\
>\mathbf{3} \text { år, } \mathbf{n}(\%)\end{array}$ & $\begin{array}{l}\text { Deltatt pá kurs i traumesykepleie } \\
\text { KITS kurs, ja, } \mathbf{n}(\%)\end{array}$ & p-verdi \\
\hline Sykepleier & $41(53,2)$ & $64(83,1)$ & $<0,003$ \\
Spesialsykepleier & $19(86,4)$ & $21(95,5)$ &
\end{tabular}


Tabellen viser at det er overvekt av sykepleiere uten videreutdanning som arbeider i de to akuttmottakene. Tabellen viser også at spesialsykepleierne har lengre erfaring fra akuttmottak.

En høy andel respondenter (85,6 prosent) har deltatt på kurs i traumesykepleie (KITS). Svært få sykepleiere hadde erfaring med mottak av hardt brannskadde pasienter, totalt 90,9 prosent oppga å ha ingen, svært lite eller lite erfaring med dette. 28 prosent oppga at de aldri hadde tatt imot en hardt brannskadd pasient.

\section{Vurdering av egen kompetanse}

Tabell 2 viser respondentenes vurdering av egen kompetanse i mottak av hardt brannskadde pasienter.

Tabell 2. Hvordan vurderer du din egen kompetanse i mottak av hardt brannskadde pasienter?

\begin{tabular}{|c|c|c|c|c|}
\hline Bakgrunn & $\begin{array}{l}\text { Svært dårlig / dårlig } \\
\mathrm{n}(\%)\end{array}$ & $\begin{array}{l}\text { Verken/eller } \\
\mathrm{n}(\%)\end{array}$ & $\begin{array}{l}\text { God / svært god } \\
\mathrm{n}(\%)\end{array}$ & p-verdi \\
\hline Sykepleier & $29(37,7)$ & $35(45,4)$ & $13(16,9)$ & $<0,001$ \\
\hline Spesialsykepleier & $2(9,1)$ & $11(50)$ & $9(40,1)$ & \\
\hline
\end{tabular}

Spesialsykepleierne vurderte sin kompetanse signifikant bedre (god/svært god, 40,1 prosent) sammenliknet med sykepleierne uten videreutdanning (16,9 prosent). Tabellen viser at 83,1 prosent av sykepleierne uten videreutdanning har vurdert sin kompetanse som lav (svært dårlig - dårlig verken/eller).

Tabell 3 viser en oversikt over respondentenes vurdering av egen kompetanse ut ifra deltakelse på KITS.

Bare de som har deltatt på KITS, vurderte sin kompetanse til «god» eller «svært god».

Tabell 3. Respondentenes vurdering av egen kompetanse ut i fra deltakelse på KITS.

\begin{tabular}{|c|c|c|c|c|}
\hline \multirow{3}{*}{$\begin{array}{l}\text { Har du deltatt på } \\
\text { KITS traumekurs? }\end{array}$} & \multicolumn{2}{|c|}{ Svært dårlig / dårlig n (\%) } & \multirow{2}{*}{$\begin{array}{c}\text { Verken/eller n (\%) } \\
44(51,8)\end{array}$} & \multirow{2}{*}{$\begin{array}{c}\text { God / svært god n (\%) } \\
22(25,9)\end{array}$} \\
\hline & Ja, n (\%) & $19(22,3)$ & & \\
\hline & Nei, n (\%) & $12(85,7)$ & $2(14,3)$ & - \\
\hline
\end{tabular}


På spørsmål om sykepleierne planlegger og er i forkant ved mottak av en hardt brannskadd pasient, svarte 77,3 prosent av spesialsykepleierne at de er gode eller svært gode til dette, mot 35,1 prosent av sykepleierne uten videreutdanning.

Ved spørsmål om respondentene har mottatt opplæring på mottak av hardt brannskadde pasienter på sin arbeidsplass, svarte 75,8 prosent av dem som har arbeidet over tre år, at de har fătt opplæring. Resultatene viser også at 36 prosent av respondentene som har arbeidet i akuttmottaket mer enn tre år, ikke har fått opplæring.

95,9 prosent av respondentene oppga ønske om mer opplæring, og 93,9 prosent $\varnothing$ nsket mer simulering/trening i mottak av hardt brannskadde pasienter - og det var ingen signifikant forskjell på spesialsykepleiere og sykepleiere.

\section{Kompetanse ved mottak av brannskadde}

Resultatene viser at få sykepleiere har erfaring med traumemottak av hardt brannskadde pasienter.

Spesialsykepleiere skårer egenopplevd kompetanse høyere enn sykepleiere uten videreutdanning. Egenopplevd kompetanse er likevel lav hos dem som har deltatt på KITS.

Sykepleieres kliniske kompetanse er essensiell for å sikre god pasientsikkerhet og høy kvalitet på pasientbehandlingen uansett behandlingsnivå (6).

Selvopplevd kompetanse er ikke et objektivt mål, men handler om hvordan personen selv opplever sin egen kompetanse på forskjellige områder (7). Sykepleiere må være bevisst på egen kompetanse og om kompetansen holder det nivået som kreves og forventes i den rollen sykepleieren har (6).

En studie viser at nyutdannede sykepleiere med kort erfaring skårer seg høyere på egenvurdering av kompetanse (8). Derimot viser vår studie at sykepleiere som har arbeidet under tre år, skårer seg lavere på kompetanse, muligens fordi vår studie baserer seg på mottak av hardt brannskadde pasienter, en pasientgruppe som det ikke sees så ofte i akuttmottak. 
Vår studie viser at sykepleiere uten videreutdanning vurderer sin kompetanse lavt, mens spesialsykepleiere vurderer sin kompetanse høyere. Spesialsykepleierne skårer også høyere på dette med planlegging og å være i forkant ved mottak av hardt brannskadde pasienter.

Cornally og medarbeidere viser at spesialsykepleiere er bedre i stand til å ta riktige avgjørelser i behandlingskrevende situasjoner enn det sykepleiere uten videreutdanning er. Formalkompetansen til spesialsykepleiere gir også en bedre forståelse av hva som krever raske beslutninger og ikke (9).

Vår erfaring fra praksis er at sykepleiere skifter arbeid etter kun kort tid i akuttmottak, og at det er en stor gjennomstrømming av personell. Desto viktigere er undervisning og kompetanseheving noe som ledere og fagutviklere må jobbe med kontinuerlig.

\section{Ønsker mer opplæring}

Flesteparten av sykepleierne $\varnothing$ nsket mer opplæring, trening og simulering på mottak av hardt brannskadde pasienter.

Capella og medarbeidere viser at simuleringer er med på å $\varnothing$ ke kompetansen samt teamets prestasjon og bedre ivaretakelse av pasienten. Å ha teamøvelser forbedrer samarbeidet i et traumemottak og effektiviserer akuttbehandlingen av en alvorlig skadet pasient (10).

Ved gjennomføring av regelmessig traumeøvelser i akuttmottak eller på simuleringssenter kan case basert på en alvorlig brannskadd pasient være med på å løfte kompetansen til sykepleierne. Det kan samtidig gjøre sykepleieren mer bevisst på sin egen rolle i traumeteamet og øke samarbeidet på tvers av profesjoner (11).

\section{$\equiv$ «Egenopplevd kompetanse øker etter gjennomført traumeøvelse.»}

Av erfaring fra praksisfeltet ser vi at egenopplevd kompetanse $\emptyset$ ker etter gjennomført traumeøvelse. I forbindelse med traumeøvelse er det rom for debrief og forslag til forbedringer, samt at det øker forståelsen av teamarbeid.

Bare de sykepleierne som hadde deltatt på KITS, rapporterte egen kompetanse som god, likevel var dette en lav andel av dem som deltok i studien. 
En studie rapporterte om en signifikant $\varnothing \mathrm{kning}$ av medisinsk kompetanse og valg- og improvisasjonskompetanse etter gjennomført KITS (7).

Bevisstgjøring av egen kompetanse bidrar til å opprettholde og forbedre sykepleierens praksis med å identifisere sykepleiernes styrker og kunnskaper og ferdigheter som behøver å videreutvikles (12). Det er viktig at sykepleierne er bevisst på sitt eget kompetansenivå, og at deres kompetanse holder det nivået som kreves i den rolle som skal fylles.

\section{Utdanning hever nivået}

Resultatene i studien vår st $\varnothing$ tter opp under at videreutdanning hever sykepleiernes kompetansenivå. I vår studie hadde kun 22,2 prosent av respondentene videreutdanning.

En studie gjort i Sverige viser at ledere i akuttmottak ønsker en spesialutdanning for sykepleiere som jobber i akuttmottak.

Når sykepleiere tar spesialutdanning, vil kompetansen $\varnothing \mathrm{ke}$, og sikre at enhetene er mer spesialiserte og komplekse.

Vår studie viser at det er behov for kompetanseheving blant sykepleierne gjennom videreutdanning (13).

\section{Svakheter ved studien}

En svakhet med vår studie kan være at det ikke ble benyttet et validert spørreskjema. Det ble ikke utført reliabilitetstester som for eksempel test-retest eller interrater-reliabilitet. Til tross for et lite utvalg ble det påvist signifikante forskjeller mellom grupper på flere av spørsmålene.

I analysen og presentasjonen av resultatene er det gjort et utvalg med tanke på hva som diskuteres, for eksempel egenopplevd kompetanse mellom sykepleier med og uten videreutdanning. Det er mulig at vi kan ha gått glipp av noen sammenhenger som kunne vært avdekket ved videre statistiske analyser.

Videre er utvalgsstørrelsen relativt liten, og funn kan ikke generaliseres. 


\section{Konklusjon}

Vår studie viser at spesialsykepleiere har høyere egenvurdering av kompetanse på traumemottak av hardt brannskadde pasienter enn sykepleiere uten videreutdanning. I tillegg vurderer spesialsykepleiere sin egen kompetanse høyere ved vurdering av forberedelser i forkant av traumemottak, samt at de kjenner sin rolle bedre enn sykepleiere uten videreutdanning.

Majoriteten av sykepleierne $\varnothing$ nsker et kompetansel $\varnothing \mathrm{ft}$ i form av opplæring og trening/simulering.

Som en videreføring av studien kunne det vært interessant å gjennomføre studien ved flere akuttmottak. Videre ville det vært interessant å se på de lokale prosedyrene for å kartlegge behovet for eventuelt å utarbeide en ny prosedyre.

\section{Referanser}

1. Sørnes L. «Sky ilden» - nasjonal informasjonskampanje: de fleste brannskader kan unngås. Stjørdal: Bladet; 13.02.2017 [oppdatert:15.02.2017; sitert 02.10.2019]. Tilgjengelig fra: https://www.bladet.no/nyheter/2017/02/13/\%E2\%80\%93-Defleste-brannskader-kan-unng\%C3\%A5s-14214827.ece

2. Helse Bergen, Haukeland universitetssykehus. Brannskadar. Helse Bergen, Haukeland universitetssykehus; 2019. Tilgjengelig fra: https://helsebergen.no/behandlinger/brannskadar (nedlastet 02.10.2019).

3. Onarheim H, Brekke R, Guttormsen A. Brannskadede innlagt i norske sykehus - en populasjonsbasert studie. Tidsskrift for Den norske legeforening. 2016;136(21):17991802.

4 Moi AL, Gulbrandsen T. Brannskader. 3.utg. I: Gulbrandsen T, Stubberud DG. Intensivsykepleie. Oslo: Cappelen Damm Akademisk; 2015.778-815.

5. Skau G. Gode fagfolk vokser: personlig kompetanse i arbeid med mennesker. 5. utg. Oslo: Cappelen Damm Akademisk; 2017.

6. Finnbakk E, Wangensteen S, Skovdahl K, Fagerström L. The professional nurse self-assessment scale: psychometric testing in Norwegian long term and home care contexts. BMC Nurs. 2015;14(1):59. DOI: 10.1186/s12912-015-0109-3 
7. Finstad J, Koldstadbråten KM, Helles $\varnothing$ R. Slik vurderer helsepersonell egen kompetanse etter traumekurs. Sykepleien Forskning. 2017;12(64387):e-64387. DOI:

$\underline{10.4220 / \text { Sykepleienf.2017.64387 }}$

8. Salonen A, Kaunonen M, Meretoja R, Tarkka M.

Competence profiles of recently registered nurses working in intensive and emergency settings. J Nurs Manag. 2007 november;15(8):792-800.

9. Cornally GMN, O'Mahoney C, White G, Weathers E. Emergency nurses: procedures performed and competence in practice. International Emergency Nursing. 2013;21(1):50-7.

DOI: 10.1016/j.ienj.2012.01.003

10. Capella A, Smith P, Philip A, Putnam G, Gilbert C, Fry $\mathrm{W}$, et al. Teamwork training improves the clinical care of trauma patients. J Surg Educ. 2010;67(6):439-43.

11. Khademian Z, Sharif F, Tabei S, Bolandparvaz S, Abbaszadeh A, Abbasi H. Teamwork improvement in emergency trauma departments. Iran J Nurs Midwifery Res. 2013;18(4):333-9.

12. Meretoja R, Isoaho H, Leino-Kilpi H. Nurse competence scale: development and psychometric testing. J Adv Nurs. 2004;47(2):124-33.

13. Andersson $\mathrm{H}$, Nilsson K. Questioning nursing competences in emergency health care. J Emerg Nurs. 2009;35(4):305-11. 